\title{
Dağılan Beyin Parçalarına Gülmek: Quentın Tarantıno Filmlerinde Șiddet ve Mizah
}

\author{
Levent Yılmazok'
}

Öz

Quentin Tarantino filmlerindeki şiddet ile mizah ilişkisini incelemeyi amaçlayan bu makale üç bölümden oluşmaktadır. İlk bölümde sinemada şiddet ve şiddetin seyirci ile ilişkisi ele alınmakta, izleyen bölüm mizah ve sinemada mizahın şiddetle ilişkisine odaklanmaktadır. Son bölümde ise Tarantino filmlerinin genel nitelikleri karakterler, anlatım özellikleri ve diyalogları üzerinden incelenip şiddet ve mizahla ilişkisi ortaya konmaktadır. Bunu yaparken mizaha ilişkin uyuşmazlık kuramından, absürt ve kara mizah kavramlarından yararlanılmaktadır.

Anahtar Kelimeler: Quentin Tarantino, Şiddet, Absürt, Kara Mizah, Uyuşmazlık Kuramı.

\section{Laughing To The Diffusing Brain Parts: Violence And Humor In Quentin Tarantino Films}

\begin{abstract}
This article, which consists of three sections, aims to explore the correlation of violence with humor in Quentin Tarantino movies. In the first section, violence in cinema and the attitude of the audience towards violence are handled. The following section focuses on humor and its correlation with the violence in cinema. The last section examines the features that are peculiar to Tarantino films through the characters, narrative styles and dialogues used and preferred by the director and the relationship between humor and violence is presented. The incongruity theory and the concepts of absurd and black humor are benefitted to reach the conclusion.
\end{abstract}

Keywords: Quentin Tarantino, Violence, Absurd, Black Humor, Incongruity Theory. 


\section{Giriș}

Q uentin Tarantino filmlerindeki şiddet ile mizah ilişkisini incelemeyi amaçlayan bu makalede üç bölümde sırasıyla sinemada şiddet, mizah ve Tarantino filmlerinin genel nitelikleri ele alınmaktadır. Illk bölümde öncelikle, filmlerde gördüğümüz şiddetin araç ve amaç olmasına göre kabaca ayrımı yapılacak, törensel, sembolik ve aşırı-gerçek şiddet türleri sınıflamasından söz edilecektir. Ardından sinemadaki şiddetin aşırılığına ve seyircinin şiddetle ilişkisine değinilecektir. Mizah ve mizahın sinemada şiddetle ilişkisinin ele alındığı ikinci bölümde yaygın mizah kuramlarından, kara mizah ve absürt kavramlarından, Amerika Birleşik Devletleri'nde daha çok çocukların izlediği animasyon filmlerindeki ve en çok gişe başarısı sağlayan komedi filmlerindeki şiddetin sıklığını ortaya koyan iki incelemeden söz edilecektir. Son bölümde ise yönetmenin filmlerindeki karakterlerin özellikleri, anlatım yöntemleri-tercihleri ile şiddetle ilişkisi ele alınacak, filmlerinde bolca bulunan kara mizaha iki örnek uyuşmazlık kuramı eşliğinde verilecektir.

\section{Sinemada Șiddet}

Filmlerde görülen şiddeti en genel anlamda, kabaca, araç veya amaç olmasına göre ikiye ayırmak olasıdır. Toplumsal belleğe hitap eden filmler, insanlığın yaşadığı büyük acıları, savaşları, yıkımları konu edinebilir ve doğaları gereği şiddet sahneleri içerebilirler. Büyük olasılıkla içerirler. Bireysel dramları anlatan filmler de, ele aldıkları hikâyelerin konularına göre ve onları seyirciye daha etkili aktarabilme saikiyle şiddet barındırabilirler. Muhtemel bir geleceği resmetmek, görünür kılmak, böylece belli bir toplumsal bilincin gelişmesine hizmet etmek amacıyla da şiddet gösterilebilir filmlerde. Bu sayılan durumlarda şiddet öğesi belli bir toplumsal veya bireysel duyarlılık yaratmak için araç işlevi görmektedir, ikincildir. Bir de, şiddeti sadece bir eğlence biçimi olarak sunan, dehşeti, vahşeti bir araç olarak değil; kendi içinde bir amaç olarak alan ve neredeyse onu kutsayan, toplumsal bağlamından, kişisel dramlardan kopuk, ortalığın kan gölüne döndüğü filmler vardır. Bu tür filmlerde belirsiz sayıda, isimleri ve kimlikleri bilinmeyen insanlar ölür, patlar, yok olur. Yapılan kaba ayrım uyarınca her iki tür için de binlerce örnek sinema tarihinin içinden kolaylıkla bulunup verilebilir. Bununla birlikte, sinemada şiddetin sunumu üzerine pek tabii ki daha birçok kategorileştirmeye de gidilebilir. Muhtemel ayrımlar içinden konumuzla doğrudan bağ kurabilecek olan biri Amerikalı eğitim bilimci Henry A. Giroux'un yaptığıdır.

Ucuz Roman (Pulp Fiction, 1994) filmi ve şiddet kültürü üzerine "Pulp Fiction and the Culture of Violence" başılıklı yazısında Giroux (1995: 301-304) görsel şiddetin üç biçimini törensel [ritualistic], sembolik ve aşırı gerçek [hyper-real] olarak tanımlar. Törensel şiddet, korku, aksiyon, Hollywood dramları gibi türlerin tekrar tekrar ve belli formüllerle ürettiği şiddeti tarif eder. Tamamen sıradan, tahmin edilebilir ve erkek klişeleriyle örülü olan bu şiddet sadece göze hitap etmekte olup yüzeysel içeriğe sahiptir. Her ne kadar seyirci şiddetin bu türden temsiliyle duygusal bağ kurabilirse de insanların karmaşık davranışlarına ve kavgalarına ilişkin pek fazla bilgi edinemez. Onca entrikaya, büyüleyici görselliğe ve yaşattığı şoklara karşın, bu tür şiddet belli formüllerin dışına çıkmaz. Sıradan olaylara müdahale etmediği gibi eleştirel bir bakıştan yoksundur. Abartıdan ve kendini tatmin etmekten öteye gitmez. Şiddetin bu tür kullanımında, yani onlarca, yüzlerce insanın öldürüldüğü filmlerde seyirciden şiddetin mekanizmaları ve yansımaları üzerine kafa yorması beklenmez. Törensel şiddet, Hollywood filmlerinin 
eğlenceden ibaret olduğu, siyasi imalarından veya mesajlarından dolayı mahkûm edilmemeleri gerektiği genel kanısını güçlendirmeye yarar.

Sembolik şiddete gelince, bu tür görselleştirmede insanın ya da toplumsal bir meselenin derininde yatan ile dışarı yansıyan şey arasında bağ kurulmaya çalışılır. Nedensellik üzerine kafa yorulur. Şiddet kendi içinde bir amaç değildir; daha geniş bir mantığa ve kavrayışa ihtiyaç duyar. Seyirciye şiddetin görsel zevkini sunmak yerine, insan eylemlerinin karmaşık çelişkilerini, aklın sınırlarını, insanları diğer insanlara ve daha geniş bir toplumsal dünyaya bağlayan varoluş meselelerini sorgular. Sembolik şiddet, görselleştirme yöntemi olarak baş döndürücü derecede hızlı kurgulanmış resimleri kullanmaz. Şiddet mekanizmalarını ve yansımalarını çeşitli çerçeve ve kesmeler aracılığıyla irdelemeyi tercih eder. Giroux bu tür şiddetin kullanımına Clint Eastwood'un Affedilmeyen (Unforgiven, 1992) filmini örnek gösterir. Ayrıca, Stanley Kubrick'in Full Metal Jacket (1987) ve Terrence Malick'in İnce Kırmızı Hat (The Thin Red Line, 1998) filmleri de bu tür kullanıma örnek olarak önerilebilir.

Daha çok 1990 sonrası filmlerde görülen aşırı-gerçek şiddet türü ise, teknolojinin yardımıyla iyice görselleştirilebilir hale gelen şiddetle birlikte gerçekçi diyaloglara, dramatik hikâye anlatımına, parodiye ve natüralizme yer verir. Törensel şiddet herhangi bir biçimde toplumsal eleştiriden uzak dururken aşırı-gerçek şiddet tartışmalı meselelerin çirkin tarafını önümüze sermekten çekinmez. İlkel duygulara hitap eden bu şiddet türü aynı zamanda ırk temelinde gitgide daha çok bölünen Amerika'da gençlerin her gün sokaklarda karşılaştığı şeyi gösterir. Bu yeni ve aşırı-gerçek şiddet, teknolojinin olanaklarından ve biçim denemelerinden yararlanmasıyla, sahip olduğu ironi, mizah ve zekice yazılmış diyaloglarla ve de 1970'lerin kültür atmosferine yaptığı saygı duruşuyla çağımızın simgelerinden biri haline gelmiştir. Bu tespitlere bir katkı olarak şunu söylemek mümkündür: aşırı-gerçek şiddet bir yandan rahatsızlık ve iğrenme duygusu uyandırırken öte yandan hikâyenin seyirciyi daha çok içine almasına yaramaktadır; çünkü, perdede görülenler şimdi ve burada oluyor gibidir. Giroux'nun bu tür filmlere Amerikan sinemasından verdiği üç örneğin ikisi Tarantino'nun Rezervuar Köpekleri (Reservoir Dogs, 1992) ve Ucuz Roman'ıdır. Tarantino filmlerindeki aşırıgerçek şiddet konusuna ileriki bölümlerde değinilecektir. Sinemada şiddet ve seyirciyle ilişkisinin burada biraz daha irdelenmesinde yarar görülmektedir.

Hangi türde olursa olsun, filmlerde şiddetin gereğinden fazla ve abartılı biçimlerde kullanıldığı iddia edilebilir, tartışılabilir. Kesin olan şudur ki, insanlar perdede şiddet görmekten, yönetmenler de şiddeti göstermekten vazgeçmemektedirler; çünkü, insan hayatında şiddet az ya da çok vardır. Görünmese de bilinir, duyulur. Seyircinin kendi hayatında olmasa da komşusunda vardır, evinde olmasa da okulunda vardır, sokakta vardır, komşu ülkelerde vardır. Bir yerlerde mutlaka vardır. Şiddetin olduğu bir dünyada, şiddetin ne olduğunu, neye benzediğini merak ettiği için seyircinin şiddeti gösteren filmleri izlediği öne sürülebilir. Özellikle, kendi gündelik hayatında belirgin olarak yoksa ya da gündelik hayatında karşılaşmadığı biçim ve yoğunluktaki şiddeti görebilmek için seyircinin böyle bir edimde bulunduğu düşünülebilir. Böylelikle 'sıkıcı' gündelik hayatta olmayan heyecan da sanal biçimde deneyimlenir. Heyecanı deneyimlemek, kişiyi film izlemeye yönelten itkilerden yalnızca biri olabilir; ama, şiddet içeren filmler için bunun daha belirgin bir gerekçe olduğu söylenebilir.

Jeffrey Goldstein (1999: 272-273), seyirciyi şiddet içeren eğlenceye veya görüntüye 
çeken şeyin her birey için faklı olduğunu, kiminin heyecan için, kiminin belli bir çevrede kabul görmek için, bazılarının da adaletin gerçekleştiğini görmek için şiddeti seyrettiğini söyler. Robert Appelbaum (2013: 122-125) ise, seyirciyi şiddet görmeye yönelten öğeleri sayarken, yukarıda değinilen merak öğesinin yanına heyecan ve oyunu da ekler. İçinde gerçek kurbanların olmadığı, seyircinin zarar görmediği bir oyun olmalıdır bu. Seyircinin zarar görmemesi önemlidir. Roma İmparatorluğu döneminde dövüş sırasını bekleyen bir gladyatör hem seyircidir hem değildir. Gladyatörü tanıyan ve onun için endişe duyan seyirciler için de durum aynıdır. Ancak, gladyatörü tanımıyorsak, izleyici için sadece bir oyuncuysa, gerçekten acı çektiğini düşünmüyorsak seyirciyizdir; tanıyorsak, sadece estetik nedenlerle seyreden biri olamayız, der Appelbaum ve Kant'ın estetik yargıya varmak için öznenin tarafsız olması gerektiği savına gönderme yapar. İlgi duydukları spor dalı şiddet içersin ya da içermesin, taraftarlarda da durum böyledir, kendi sporcularıyla veya takımlarıyla özdeşlik kurarlar ve estetik yargıya varamazlar, der.

Tam da burada Kant'ın estetik yargı üzerine düşüncelerine değinmekte yarar var. Kant (1987: 46-48), beğeni söz konusu olduğunda, bir şeyi yargılayan öznenin objektif bir karara varabilmesi için yargıladığı şeye karşı en küçük bir önyargısı olmaması gerektiğini söyler. Aksi durumda duygular devreye girecek, yapılan iş estetik bir yargıya varmak değil, hoşlanma, keyif alma, memnuniyet duyma veya tam tersi olacaktır. Hoşlanan kişi ise kendini yargılamaktan muaf tutan, yargılamaktan vazgeçen özne demektir.

Bir filmde seyirci şiddet uygulayanla ya da şiddete maruz kalanla özdeşlik kurmakta mıdır? Kendi özdeşlik kurduğu bir karakterin - doğal olarak - tarafını tutmakta, onunla gülmekte, onunla ağlamakta mıdır? Yoksa - taraf tutmaksızın - sadece şiddeti izlemekten mi haz duymaktadır? Bu sorular sorulduğunda varılacak sonuç, şiddet filmlerinin seyircisi açısından şiddetin genellikle adaleti sağlamaya yarayan, suçluları cezalandıran, filmdeki 'iyi'den yana bir olgu olarak, bir araç olarak öne çıktığıdır. Çoğu seyirci için durumun böyle olduğu, şiddetin kendi içinde amaç olmadığı ve şiddeti uygulayan ya da şiddete maruz kalan kişilerin seyircinin perdedeki temsilcileri olduğu söylenebilir.

Kant'ın estetik yargı üzerine öne sürdükleri bağlamında, seyircinin filmdeki şiddet karşısında salt estetik kaygılardan mürekkep bir yargıya varamayacağı, yani objektif olamayacağı, şiddeti gerçekleştirenin kimliğine göre vereceği tepkinin memnuniyet ya da rahatsızlık olacağı beklenmelidir. Ancak, her ne kadar tarafını tuttuğu 'iyi'den yana işlev gördüğüne ve adaleti sağladığına inansa da, seyircinin çoğu şiddet sahnelerini izlemekte zorlanır. Dayanılmaz, hatta bazen iğrenç gelir seyirciye şiddet sahneleri. Ama yine de seyirci şiddet filmlerini izlemeye devam eder. Anlaşılan o ki, filmi izlemekle kazanılan, kaybedilenden fazladır.

Sinemada şiddet, filmlerde gösterilen şiddetin türleri ve seyircinin şiddetle ilişkisi üzerine yapılan girizgâhtan sonra, izleyen bölümde sinemada mizah ve şiddetle ilişkisinden söz edilecektir.

\section{Mizah, Șiddet, Kara Mizah}

Mizahın kültürel analizini yapmak kolay değildir. Mizahın evrensel olduğu, yani 
bütün toplumların iyi kötü bir mizah anlayışı olduğu ve belli durumlara her zaman, her yerde, her kültürde gülünebileceği söylenebilir. Tam tersine, kültürel faktörlerin ve yerel öğelerin mizahı üretmede ve anlamada önemli oranda belirleyici olduğu da iddia edilebilir. Özellikle, sözlü-yazılı mizahın başka bir dile çevrildiğinde aynı etkiyi yaratması kolay değildir. Ayrıca insanların neye güldükleri yaşa, cinsiyete, eğitim durumuna, sosyal statüye ve hatta mesleklere göre değişebilir.

Simon Critchley (2002: 2-3), mizah ve kahkahaya ilişkin pek çok kuram içinde John Morreall'ın sınıflandırmasını esas alarak özellikle üçünü, üstünlük [superiority], rahatlama [relief] ve uyuşmazlık [incongruity] kuramlarını öne çıkarır. Gerçekten de çoğu mizahi durum için bu üç kuramın açıklayıcı nitelikte olduğu söylenebilir. Üstünlük kuramına göre, diğer insanlardan üstün olduğumuz duygusuyla onların zayıflıklarına, düştükleri zor durumlara güleriz. Bu kuram Platon ve Aristoteles'e kadar götürülmektedir. Platon, kahkahanın fesattan kaynaklandığını söylemiştir (Martin, 2007). Üstünlük kuramı 18. yüzyıla kadar felsefeciler arasında itibar görmüştür. En tipik örneği, insanların etnik kökenlerinden veya milliyetlerinden dolayı aşağı görülüp espri konusu yapıldıkları etnik mizahtır. Rahatlama kuramı, 19. yüzyılda Herbert Spencer tarafından ortaya atılıp daha sonra Sigmund Freud tarafından geliştirilmiştir ve buna göre kahkaha bedende hapsedilmiş gerginliğin boşaltılmasıdır. Freud mizahı espriden, fıkradan ve nükteden ayrı bir yere koymakta, sadece az sayıda şanslı insanın sahip olduğuna inandığı mizahi tavrı, gerçek dünyadaki baskın nahoş duygulara karşı en etkili savunma mekanizması olarak önemsemektedir (1928; 2012). Uyuşmazlık kuramına göreyse, mizahı yaratan bildiğimiz ya da beklediğimiz durum ile espride, şakada ya da mimikte gerçekleşen durum arasındaki uyuşmazlık hissidir (Critchley, 2002). Komik olan şeyler, uyuşmaz, sürprizli, tuhaf, olağan dışı ya da beklenenden farklı olanlardır ve geçmiş 250 yıl içinde pek çok düşünür ve kuramcı uyuşmazlığın mizahın temeli olduğu düşüncesini savunmuştur (Martin, 2007). Üstünlük ve rahatlama kuramları mizahın duygusal tarafını öne çıkarırken uyuşmazlık kuramı bilişsel boyutuna odaklanmaktadır. Tarantino filmlerine değinilirken uyuşmazlık kuramı biraz daha detaylandırılacaktır.

Ele alınan konu bağlamında, seyircinin sinemadaki şiddetle ilk önce mizah aracılığıyla tanıştığını tespit etmek gerekir. Çocuklukta izlenen çizgi filmlerin önemli bir kısmı şiddet içermektedir, ama şiddet edimleri komik biçimlerde gerçekleşir. Mickey Mouse'u, Tom ve Jerry'i, Bugs Bunny'yi, Şirinler'i ve onlarcasını daha hatırlamakta yarar var. Komik şiddet de daha sinemanın ilk yıllarında slapstick denen durum komedisi filmleriyle başlamıştır. Bu tür komedilerin ilklerinden biri olarak Lumière kardeşlerin Bahçıvan (L'arroseur Arrosé, 1895) filmi en sık örnek verilenlerdendir. Bahçeyi sulamakta olan bahçıvanın suyu, arkasından gelip hortuma basan çocuk yüzünden kesilir. Suyun neden kesildiğini anlamaya çalışan bahçıvan yaklaşıp hortuma bakarken çocuk hortumun üzerinden ayağını çeker ve tazyikli su bahçıvanın yüzüne gelir. Bahçıvan da çocuğu yakalayıp ona vurur. Komik şiddetin filmlerdeki varlığı sinema tarihi boyunca artarak sürmüştür.

Amerika Birleşik Devletleri'nde 1937 ile 1999 arasında sinemalarda gösterime girip daha sonra video kasetleri piyasaya sürülen, 'genel izleyici' için uygun olarak sınıflandırılmış 74 animasyon filmi üzerinde yapılan bir çalışma (Yokota ve Thompson, 2000) daha çok çocukların izlediği bu tür filmlerde şiddetin yaygınlığını ortaya koymaktadır. Baskı yapmak, zarar vermek ya da eğlence için bir karakterin bir diğeriyle yaralayabilecek veya zarar verebilecek biçimde fiziki temasta bulunduğu eylemler 
şiddet olarak değerlendirilmiştir. Bütün filmlerde en az 1 şiddet eylemine rastlanmış, her bir filmde görülen şiddetin ortalama süresi 9.5 dakika gibi yüksek bir rakam olarak gözlenmiştir. Filmlerin yaklaşık yarısında en az bir karakter şiddet eylemine neşeyle veya kahkahayla eşlik etmiş, buna karşılık 24 filmde bir karakter şiddet karşıtı mesaj dillendirmiştir. Filmlerde toplam 125 yaralanma kaydedilmiş, kötü karakterler diğerlerine oranla daha çok ölmüştür. Şiddet eylemlerinin çoğunluğu kötülerle hesaplaşan iyi veya nötr karakterler tarafından gerçekleştirilmiş, karakterler şiddet eylemlerinde çok çeşitli silahlar kullanmışlardır.

Amerika Birleşik Devletleri'nde gerçekleştirilen ve 1951-2000 arasında her yıl en çok gişe başarısı gösteren komedi filmlerinin incelendiği başka bir araştırma ise (Mclntosh vd., 2009) bu 50 komedi filminde şiddetin çok yaygın olduğunu ve bu durumun 1970 'lerden itibaren daha da çok görüldüğünü ortaya koymaktadır. Araştırmacılar filmleri 5'er dakikalık bölümlere ayırarak izlemişler, her bir 5 dakikalık bölümde insanın insana fiziksel zarar verdiği en az bir sahne görüldüğünde bu, şiddet içeren sahne olarak kaydedilmiştir. Bu filmler içinde en çok şiddet sahnesi içerenler Gençlik Yılları (American Grafiti, 1973), Gümüş Eyerler (Blazing Saddles, 1974), Pembe Panter'in Dönüşü (The Return of the Pink Panther, 1975), Ahmak (The Jerk, 1979), Trading Places (1983), Evde Tek Başına 2 (Home Alone 2: Lost in New York, 1992) ve Avanak Ajan (The Spy Who Shagged Me, 1999) olarak ortaya çıkmaktadır. Özellikle toplumsal kriz ve bunalım zamanlarında, işsizliğin, cinayetlerin, intiharların ve boşanmaların artış gösterdiği dönemlerde komedi filmlerindeki şiddetin de fazlalaştığı görülmektedir.

Dalga geçilmesi düşünülemeyecek, ciddi konu ve durumları komedileştirip absürt bir durum yaratan ve Tarantino filmlerinde sık tanık olunan kara mizah ise sinemanın daha geç döneminde filmlere girmiş ve son yıllarda görülme sıklığı artmıştır. Kara mizah kavramı, tam bir tanımını vermemekle birlikte ilk defa André Breton tarafından kullanılmış ve ilk kullanıldığında anlaşılamamıştır. Daha sonra yaygınlaşmış ve sözlüklere girmiştir. Breton, kara mizahı başlatan kişi olarak Jonathan Swift'i işaret eder (2009: 29). Freud'un (2012: 258-259) 'darağacı mizahı'nı [galgenhumor] örneklediği espri Breton dahil pek çok kaynakta tipik bir kara mizah örneği kabul edilir. Bir pazartesi günü idama götürülen kişi “Güzel, hafta iyi başlıyor” sözünü eder. Freud'un deyimiyle bu 'anlamsız bir biçimde yersiz' bir espridir çünkü o hafta o kişi için başka bir olay gerçekleşmeyecektir. Çoğu zaman güldüğümüz şeyle bir sorunumuz olduğunu; çünkü, o şeyin izleyiciyi bir şekilde ürküttüğünü savlayan Critchley (2002: 56-57), Groucho Marx'ın anlattığı, Freud'ünküne benzer bir idam hikâyesini aktarır. İdam mahkûmu, son sözünü soran rahibe idam sehpasının güvenli olduğunu sanmadığını söyler. Burada geçen örneklerin açıkça ortaya koyduğu üzere kara mizah ile absürt çok zaman iç içedir.

Sözlük anlamı 'saçma', 'anlamsız', 'boş' vb. olan absürt, mantıksız, çelişik, çizgi dışı, alışıldık olmayan veya komiklik derecesinde alakasız durumlar için kullanılabilmektedir. İlk örnekleri edebiyatta verilen ve Birinci Dünya Savaşı sonrasında büyük oranda artış gösteren kara mizah diğer sanatların ve bu arada sinemanın da ilgi alanına girmiştir. Kara mizahın daha sert örnekleri toplumsal çalkalanmaların daha çok olduğu dönemlerde ortaya çıkmakta, herkesi, her kavramı, kişiyi, kurumu, kuralı hedef alabilmektedir. Breton'a göre kara mizah duygusallığın ölümcül düşmanıdır (2009: 25). Enis Batur (2010: 10) ise kara mizahın ironiyle farkını ortaya koyarken onun karanlık ve umutsuz tarafını deşifre etmektedir: 
Heccav, yergici, ironi ustası temelde umutlu, değişimden ve evrimden yana olan kişidir: Sövüyor, makaraya alıyor ya da çuvaldız batırıyorsa, "daha iyi bir dünya"nın varığına yatırım yaptığı içindir. Kara Mizahçı için ise böyle bir umut yoktur: Bir kıyamet habercisi gibi umudun, değişim özleminin, evrime olan inancın altında saklanan ikiyüzlülüğe tutar ışığını. Ona göre, başlangıçtan bu yana hiçbir şey değişmemiştir ve bu kanlı maskaralıkta, yani Hayat'ta kendisine düşen görev peçeyi düşürmektir.

Öte yandan, dünyanın kendisinin zaten absürt ve saçma, yanlışlıklarla, haksızlıklarla dolu bir yer olduğundan hareketle, böylesine anlamsız bir dünyada absürt'ün aslında doğal; hatta, normal olduğu düşüncesine de pekâlâ varılabilir ve gündelik hayatımızda absürt'ün sıklığı gözlemlenebilir. Henri Bergson (2003), biraz uzaktan, alakasız baktığımızda pek çok dramın komediye dönüşeceğinden, dans etmekte olan insanlara kulağımızı tıkayıp müziğin sesini duymadan bakarsak durumun ne kadar saçma görüneceğinden söz ederken ve acaba insan davranışlarından kaç tanesinin böylesi bir testi geçebileceğini sorarken bu duruma işaret etmekteydi. Albert Camus (1962) ise, felsefi bir sorun olarak gördüğü 'intihar' konusunu ele aldığı Sisyphe Efsanesi kitabında absürt'ü farklı bir anlamda kullanmış ve kavrama insan hayatı açısından büyük önem atfetmiş, insanın iradesiyle dünya arasındaki çelişkiyi kavramada bir başlangıç noktası kabul etmiştir.

Bu bağlamda, kendisi zaten absürt olan bir dünyada yaşayan seyirciye, hayatın içinde hazır bulunan absürt durumları filmlerde göstermek, kara mizahın kaçınılmaz bir öğesi olarak ortaya çıkmaktadır. Örneklerine birazdan Tarantino filmlerinde değinilecektir.

\section{Tarantino Filmleri}

Quentin Tarantino filmleri sinemaseverler ve sinema üzerine yazanlar tarafından en genel anlamda 'bağımsız sinema' adı altında anılmakta, bağımsız sinemanın iyi örnekleri olarak belli bir saygı görmektedir. Bununla birlikte, Tarantino'nun saygı duyup selam gönderdiği, 1970'li yılların vurdulu-kırdılı, şiddet içerikli, B sınıfı veya grind-house tabir edilen filmlerini düzelterek, estetize ederek ve içine kara mizahı sokarak sinema sanatının iyi örneklerini verdiğini, bu tür filmlere bir itibar kazandırdığını da not etmek gerekir. $^{2}$ Tarantino ve Robert Rodriguez'in grind-house türüne selam göndermek için 2007'de yaptıkları iki film, Ölüm Geçirmez (Death Proof) ve Dehşet Gezegeni (Planet Terror), yalnız temaları ve anlatım biçimleriyle değil, jenerikleri, fragmanları ve hatta efekt olarak eklenen çizikleriyle de 1970’lerden çıkıp gelmiş gibidirler.

Bağımsız tabir edilen filmlerde marjinal karakterler veya tipler, etnik azınlıklar, farklı cinsel kimlikler, çeşitli alt kültürlerden insanlar bol olur. Tarantino filmlerinin başlıca karakterleri arasında da, suç dünyasının parçası olduklarından şiddetle iç içe yaşayan

2 Grind-house kavramı, belli türde sinema salonlarını ve o salonlarda gösterilen filmleri tanımlamak için kullanılmaktadır. Filmler şiddetle, cinselliğin ön plana çıkmasıyla ve ucuzlukla özdeşleştirilir. Ucuzluk sadece filmlerin düşük maliyetle üretilmesine değil, sinemasal kalitelerine ve gösterildikleri salonların niteliğine de işaret eder. Bilet fiyatlarının diğer sinema salonlarından düşük olduğu salonlarda filmler aralıksız, çoğunda 'iki film birden' veya 'üç film birden' gösterilir. Filmlerin vizyonda kalma süreleri diğer salonlara göre daha kısadır. Genellikle erkek seyirciye hitap eden bu tür filmlerin altın çağı batı ülkelerinde 1960-80 arasıdır. Türkiye'de de son yıllarda sayıları hayli azalmakla birlikte 1970'lerin ikinci yarısında bu tür salonların çok sayıda olduğu bilinmektedir. Grind-house filmlerin popülerliği bitince bu tür filmleri gösteren salonlar birer birer kapandı ve filmler varlığını 1980'ler boyunca video kasetlerde sürdürdü. Yönetmenin son üç filmi Soysuzlar Çetesi (Inglourious Basterds, 2009), Zincirsiz (Django Unchained, 2012) ve The Hateful Eight'i (2015) bu türün dışında tutmak gerek; ayrıca seçeceği tür ve temaların bundan sonra hangi yönde devam edeceğini kestirmek de zor görünüyor. 
çok sayıda insan vardır. Rezervuar Köpekleri'nde elmas soygunu yapan çetenin bütün elemanları, Ucuz Roman'da Marsellus Wallace (Ving Rhames), Vincent Vega (John Travolta) ve Jules Winnfield (Samuel L. Jackson), Jackie Brown'da (1997) Ordell Robbie (Samuel L. Jackson) ve Louis Gara (Robert de Niro), The Hateful Eight'te kelle avcıları John Ruth (Kurt Russell), Binbaşı Marquis Warren (Samuel L. Jackson), başına ödül konmuş ve yakalanmış Daisy Domergue (Jennfifer Jason Leigh) ile onu kurtarmaya çalışan Bob (Demián Bichir), Oswaldo Mobray (Tim Roth), Joe Gage (Michael Madsen) ve Jody (Channing Tatum) ilk akla gelenler. Bununla birlikte, suç dünyasından olmasalar da şiddete ve suça bulaşmak zorunda kalan (örneğin Ucuz Roman'da Butch Coolidge (Bruce Willis), Jackie Brown'da Jackie Brown (Pam Grier)), hayatta istediğini elde edememiş (örneğin Ucuz Roman'da Mia Wallace (Uma Thurman), Jackie Brown'da Jackie Brown ve Max Cherry (Robert Forster)), mizah duygusuna sahip (örneğin Rezervuar Köpekleri'nde Joe Cabot (Lawrence Tierney), Jackie Brown'da Ordell, Kill Bill Vol.2'de (2004) Pai Mei (Chia-Hui Liu), Zincirsiz'de Dr. King Schultz (Christoph Waltz)) ve ahlaki sorgulamalar yapan (örneğin Ucuz Roman'da Jules ve Vincent, Zincirsiz'de Django (Jamie Foxx)) karakterler Tarantino filmlerinde sıklıkla görülmektedir.

Yönetmenin filmlerinde ölenlerin önemli bir kısmı adı sanı belli, seyirciye tanıtılan, günlük konulara dair konuşmalarına seyircinin tanık olduğu insanlardır; gangster olsalar bile durum değişmemektedir. Seyirci bu karakterlerin iç dünyalarını tanıma fırsatı bulur ve kendisi gibi ‘sıradan' insanlara benzediğini görür. Örneğin, Ucuz Roman'da Vincent Vega gece boyunca eşlik ettiği patronunun eşi Mia Wallace'ı evine bıraktığında Mia tarafindan bir içki içmeye davet edilir ve tuvalette aynanın karşısında, yaşanmakta olan duruma ilişkin ahlaki sorgulama yapar:

Bir içki. Hepsi bu kadar. Kabalık yapma. İçkini iç, ama çabuk ol. İyi geceler, deyip ayrıl. Bu tam bir ahlak dersi. Ne kadar sadık olduğunu göster. Sadık olmak çok önemlidir. Çık şimdi, "iyi geceler" de, "harika bir akşamdı". Arabana bin. Eve git. Masturbasyon yap. Oldu bitti.

Klişe mafya tetikçisi kimliğinden sıyrılmış, kendi karakteri olan, kişiliğinin farklı boyutları tanıtılan, derinliği gösterilen Vincent Vega başka bir evin tuvaletinde, o eve kendisi için değerli kol saatini almaya gelmiş Butch Coolidge tarafından öldürüldüğünde duruma üzülen seyirci sayısının hiç de az olmayacağı düşünülmelidir. Başka bir filmde sıradan ve seyirciye önemsiz gösterilecek bir ölümle hikâyeden çıkıp gidebilecek böylesi karakterler Tarantino filmlerini daha önce değinilen törensel şiddet türünden azat etmeye yaramaktadır.

Tarantino, filmi dahil olduğu o türden yapan tipik özellikleri bazen yok etmekte, atlamakta, filme koymamaktadır; bu bağlamda şiddet içerikli filmlerin genelinden ayrılmaktadır. Aksiyon filminde aksiyonu, kavgayı atlayabilmektedir. Örneğin Rezervuar Köpekleri'nde filmin konu edindiği soygun, Ucuz Roman'da bahis maçına çıkan boksör Butch Coolidge'in kaybettiği maç hiç gösterilmez. Bazen de tam tersine, yönetmen, filmi aksiyon filmi yapan özellikleri görkemli, hatta abartılı biçimde görselleştirmektedir. Kill Bill Vol.1'de ana karakter Gelin'in (Uma Thurman) intikam almak için gittiği ve kim bilir kaç kişinin öldüğü O-Ren Ishii'nin (Lucy Liu) mekânında geçen sahne, Kill Bill Vol.2'de Gelin'in Kungu Fu'nun gizemlerini öğrenmek için gittiği Pai Mei adlı Çinli usta ile dövüş ve eğitim sahneleri, Zincirsiz'de Django'nun eşini kurtarmak için ikinci defa 
gittiği Candie Çiftliği'ndeki büyük evi havaya uçurması, Ölüm Geçirmez'de Dublör Mike'ın (Kurt Russell) üç kızın arabasıyla çarpışma sahnesi örnek gösterilebilir.

Tarantino'nun dikkate değer bir özelliği de filmlerinde klasik Amerikan sinemasında pek rastlanmayan uzunlukta konuşmalara yer vermesidir. Konuşmalar, yaşanmış, yaşanmakta veya yaşanacak olan gerilimle alakasız durduğu için seyirciye komik gelir. Bu bağlamda, yukarıda mizah kuramlarından söz edilirken anılan uyuşmazlık kuramını örneklemektedirler. Bu tür diyalogların filmin hikâyesine bir şey katmadığı iddia edilebilir ama yıllar geçse de seyircinin filmlerden hatırlayacağı, akılda kalıcı bu konuşmalar olacaktır. Ucuz Roman'da patronları Marsellus Wallace'ı aldatan gençleri infaz etmeye giden Vincent Vega ile Jules Winnfield arasında Avrupa ile Amerika'nın esrar, hamburger ve sinema salonlarında bira içilebilmesi üzerinden kültürel karşılaştırması, ayak masajı diyaloğu, Rezervuar Köpekleri'nde soygun çetesi üyelerinin restoranda Madonna'nın Like a Virgin şarkısı ve garsonlara bahşiş verilip verilmemesi üzerine tartışmaları ile The Hateful Eight'te idamda görev alan cellatın tutkusuzluğu ve adaletin yerine getirilmesi arasındaki ilişki üzerine akıl yürütme bu tür konuşmalar arasında ilk akla gelenlerdir.

Tarantino filmleri suç ve şiddet dünyasında geçtikleri için şiddet içermeleri eşyanın doğasına uygundur ve Hollywood suç filmlerinin kavga-dövüş, insan öldürme ile tipik suç filmi karakterleri gibi bütün klasik öğelerini barındırırlar. Kill Bill filmleri bir intikam hikâyesi olarak şiddete zemin sağlamaktadır. Rezervuar Köpekleri, Ucuz Roman ve The Hateful Eight'te karakterlerin yaşadığı zaten bir şiddet dünyasıdır. Soysuzlar Çetesi, savaşın doğası gereği şiddetin görselleştirilmesine çok uygundur. Ancak, bunların ötesinde, yönetmen filmlerde şiddeti özellikle sevdiğini ifade etmektedir: “Gerçek hayattaki şiddet, Amerika'nın en kötü taraflarından biridir. Ama filmlerde acayip eğlencelidir!..”3 Ayrıca şiddetin görselleştirilmesini sadece estetik bir tercih olarak görmektedir:

\begin{abstract}
Bence, şiddet tamamen estetik bir konu. Filmlerdeki şiddetten hoşlanmadığınızı söylemek, filmlerdeki dans sahnelerinden hoşlanmadığınızı söylemek gibi bir şey. Ben filmlerdeki dans sahnelerini seviyorum, ama sevmeseydim de bu, dans sahnelerinin çekilmesine engel olmam gerektiği anlamına gelmezdi. Filmlere şiddet sahneleri koyduğunuzda bundan hoşlanmayacak çok sayıda kişi olacaktır, çünkü bu onların aşamayacağı bir dağ. Bu izleyiciler aptal değiller. Sadece şiddet hoşlarına gitmiyor. Hoşlarına gitmesi de gerekmiyor. İzleyebilecekleri başka şeyler var. O dağı aştıklarında, önlerine aşmaları gereken bir başka dağ daha çıkartacağım. (Peary, 2010: 76, içinde)
\end{abstract}

Yönetmenin filmlerde şiddeti eğlenceli bulduğu kendi filmlerinden açıkça anlaşılmaktadır; gerçekleşen şiddet sahnelerinde dramatik durumun gerektirdiğinden daha fazlasına yer verdiğini, kana ve şiddete sevgi beslediğini, şiddeti estetize ettiğini gözlemlemek zor değil. Öyle ki, kimi zaman Tarantino filmlerinin şiddet sahnelerinde filmsel zaman yerini gerçek zamana bırakmaktadır. Yani şiddet eylemi veya şiddetin getirdikleri seyirciye, gerçek hayattaki süresi kadar gösterilir. Klasik sinemanın tersine, seyirci şiddeti bütünüyle, nahoş yanlarıyla birlikte görür. Bu da genellikle rahatsız edicidir. Rezervuar Köpekleri'nde Mr. Orange'ın (Tim Roth) kan kaybından ölmekte olduğu sahne örnek gösterilebilir. Bu sahne için yönetmen şunları söylüyor: 
...[bu] sahnenin insanları ürkütmesinin tek sebebi teatral değil gerçekçi olması. Birisi midesinden o şekilde vurulunca kan kaybından ölür. Mideden vurulmak olabilecek en acılı vurulma şeklidir, çünkü mide parçalanınca bütün o asitli sıvılar bedeninize yayılır. Acıyı hissetmeyecek kadar uyuşana dek korkunç, dayanılmaz bir acı içinde kıvranırsınız. Evet, o sahnedeki kan gerçekçi. Sette vurulan karakterin etrafında oluşan kan gölünü kontrol eden bir doktor vardı ve bize, "Tamam, biraz daha kan kaybederse ölür," diyordu. (Peary, 2010: 19-20, içinde)

Belli ki sahnenin gerçekçi olması için elden gelen özen gösterilmiştir; bu, daha önce Giroux'un sözünü ettiği, sinemada aşırı-gerçek şiddete tam uyan bir örnektir. Ayrıca 'nigger' (zenci) sözcüğünün Tarantino filmlerinde sık geçmesi Giroux'un aşırıgerçek şiddet içeren filmler için tespit ettiği Amerika'daki ırk ayrımcılığı sorununu da örneklemektedir. Zira, A.B.D.'de beyaz ırktan birisi kendilerine bu sözcükle hitap ettiğinde bunu aşağılama kabul eden Afrika kökenli Amerikalılar'ın aynı sözcüğü kendi aralarında sık kullandıkları bilinmektedir ve yönetmen duruma dikkat çekmektedir.

Tarantino filmlerinde seyircinin Hollywood'un belli kalıpların dışına çıkmayan diyaloglarından başka bir şey bulduğu not edilmişti. Bol küfürlü, popüler markalarla ilgili tespitler veya anekdotlardan yukarıda sözü edilen ayak masajı diyaloğuna, eski şarkılardan veya şarkıcılardan başka bir yönetmenin önemsiz sayıp üzerinde durmayacağı herhangi bir konuya kadar diyalogların çeşitliliği ve zenginliği yönetmenin filmlerinin ayırıcı özelliğidir, denebilir. Bu konuşmaları yapanlar, bu çeşitlilik içinde konuların en ince detaylarına giren kahramanlar ekstrem tipler, mesela gangsterler, olduğunda seyirci onların insan tarafını görmektedir. Beklenmedik bu tür konuşmalar ve küfür filme zaten belli bir mizah katmaktadır. Bir de bu konuşmalar șiddet sahnesinin içinde, öncesinde veya sonrasında gerçekleştiğinde ya da şiddete ilişkin olduğunda durum kara mizaha dönmektedir. Böylelikle, normalde en dehşet verici olabilecek sahneler aynı zamanda filmin en komik sahnelerine dönüşmektedir. İzleyen iki paragrafta bu sahnelere dikkat çekici iki örnek verilecektir.

Ucuz Roman'da Marvin'in (Phil LaMarr) kazayla ölümü ve sonrasında yaşananların filmin en komik sekanslarından biri olduğu söylenebilir. Marsellus Wallace'u aldatan gençlerin infazından dönerken arabayı Jules kullanmakta, Vincent önde oturmaktadır. Jules'un bu mafyatik hayatı artık bırakması konusunu aralarında tartışırlarken düşüncesini almak için Vincent arka koltukta oturan Marvin'e döner. Ancak Vincent'ın elindeki silah Marvin'in yüzüne doğrulmuştur ve kazayla ateş alır. Yüzünden ve kısa mesafeden vurulan Marvin'in beyin ve kafatası parçaları arabanın her yanına dağılır. Cesedin yok edilip arabanın temizlenmesi gerekmektedir. Jules yakınlarda oturan arkadaşı Jimmy'yi (Quentin Tarantino) arar ve onun evine giderler. Jules, Jimmy'den çekinmektedir. Jimmy de bir buçuk saat sonra işten eve dönecek olan eşinden çekinmektedir. Jules kendisine yardım etmesi için Marsellus'u arar ve durumu anlatır. Onca insanı öldürmüş, şiddetin her türünü görmüş, suç dünyasının bu 'kötü' adamları Jimmy'nin hemşire eşinden çekinmektedirler. Marsellus 'sorun çözücü' Mr. Wolf'u (Harvey Keitel) gönderir. Jimmy’nin eşinin işten dönmesine kırk dakika kalmıştır ve Mr. Wolf bir otorite olarak duruma el koyar; arabanın temizlenmesi, cesedin bagaja saklanması talimatlarını verir ve araba ile cesedin yok edilmesini arkadaşı Canavar Joe'yu arayarak organize eder. Sonra da Jules ve Vincent'ı tazyikli suyla yıkar, kan içinde kalmış siyah takım elbiselerinin yerine üstlerine giymeleri için şort ve tişört verir. Tarantino'nun şiddet ile mizahı harmanladığı bu sekansta seyirci bol miktarda kan lekesi görür. 
Kara mizah kullanımına başka bir örnek de Zincirsiz filminde Dr. King Schultz ile Django'yu öldürmeye gelen ırkçıların kafalarına geçirdikleri çuvallar yüzünden önlerini görememeleri üzerine yaptıkları konuşmadır. Irkçı beyazlar saldırı öncesi ellerinde ateşler, atların üzerinde toplanmışlardır. Big Daddy (Don Johnson) konuşmasında Dr. Schultz ile Django'yu nasıl işkenceyle öldüreceklerini söyler ve beyaz çuvalı kafasına geçirir. Toplanmış diğer ırkçıların da kafalarında beyaz çuvallar vardır. Big Daddy çuvalın içinden çevreyi rahat göremediğini söyleyince diğerleri de deliklerden şikâyet etmeye başlar. Delikleri büyütmeye çalıştıklarında çuvallar yırtııı. Eşi çuvalları hazırlamış olan Willard (Christopher Berry) eleştiriler üzerine duruma bozulur ve küfür edip ortamdan ayrılır. At sürerken çuvalları takmanın şart olup olmadığını tartışırlar ve en sonunda Big Daddy baskında atların görmesinin yeterli olduğunu söyler, konu kapanır. Başlarında çuvallarla saldırıya geçerler, çoğu Dr. Schultz ve Django tarafından öldürülür.

Yukarıda anılan sahneler bağlamında mizahta uyuşmazlık kuramını tekrar hatırlamakta yarar var. Rod A. Martin (2007: 62-66) bu kuramları açıklayıcı biçimde özetlemektedir. Uyuşmazlık kuramına ya da uyuşmazlığı merkezine alan muhtelif kuramlara göre bir şeyin mizahi olup olmamasında belirleyici etmen uyuşmazlık algısıdır. İnsana komik gelen şeyler, uyuşmaz, sürprizli, tuhaf, olağan dışı ya da beklenenden farklı olanlardır. 18. Yüzyılda Beattie, kahkahanın iki ya da daha fazla sayıda tutarsız, uygunsuz veya uyuşmaz parça veya koşulun aynı nesnede bir araya gelmesinden kaynaklandığını söylemiştir. Arthur Schopenhauer, kahkahayı bir kavram ile o kavramla bağıntılı düşünülen nesneler arasındaki ani uyuşmazlık algısının ifadesi olarak görmektedir. Mizah tam da bir şeye ait duyusal algılarımız ile o şeye ilişkin soyut bilgimiz veya kavramlarımız eşleşmediği veya çatıştığı durumda gerçekleşmektedir. Hans Eysenck ise kahkahayı nesnel olarak deneyimlenen, birbiriyle çelişik veya uyuşmaz düşüncelerin, tavırların veya duyguların aniden bütünleşmesine bağlar. Arthur Koestler konuya ilişkin 'bisosiasyon' [bisociation] kavramını önermiştir; buna göre bir durum, olay veya düşünce eş zamanlı olarak kendi içinde tutarlı ama birbiriyle bağdaşmayan, benzeşmeyen iki referans çerçevesi perspektifinden algılanırsa bisosiasyon gerçekleşir. Böylece tek bir olay aynı anda iki farklı dalga boyunda yankılanır. Birbirini bütünleyen bu kuramlara göre bir biçimde uyuşmazlık mizah için gerekli önkoşul gibi görülse de asla tek başına yeterli olmayacaktır çünkü bütün uyuşmazlıklar (kaldırımda yürürken araba çarpması gibi) komik değildir (Martin 2007: 63-64). Komik olmak için başka bir şeyler daha gerekmektedir. Tarantino filmlerinden yukarıda anılan örnekler bu gereklilikleri karşılar görünmektedir.

Birinci örnekte seyircinin görmekte zorlanacağı boyuttaki bir şiddet sahnesi (araba içinde yakın mesafeden vurulması ile bir insanın beyninin dağılması) ve sonrasında yaşananlar sıradanlaştırılarak komik hale sokulmaktadır. Seyircide, olayın bütününe ilişkin bir uyuşmazlık algısı oluşmaktadır. Birinin talihsiz ölümü gibi trajik bir durum ile olayın faili ve tanığının duruma üzülmek vb. tepkiler vermek yerine cesedin yok edilmesi çabasına girmeleri ama öte yandan da cinayet işlemiş insanların telaşından uzak olmaları birbiriyle uyuşmamaktadır; tuhaftır, olağan dışıdır ve seyircinin beklentisinden farklılık göstermektedir. Sonrasında, bir sürü insan öldürmüş gangsterlerin Jimmy'nin eşinden çekinmeleri, sorun çözücü Mr. Wolf'un eksantrik bir karakter biçiminde resmedilmesi seyircide gülme tepkisini doğurmaktadır. Seyircinin, doğası gereği bir sürü olumsuz şeyi çağrıştıran cinayete ilişkin soyut bilgisi, sonrasında yaşananların kendisinde yarattığı duyusal algılarla eşleşmemektedir. Cinayet ile onu izleyen komik durumların aynı sekansta birleşmesiyle, birbiriyle çelişik duygular da bütünleşmektedir. 
Son tahlilde, gerçekleşen olayın bütünü seyirci tarafından bir yanda ölüm, kan ve şiddet, öte yanda Jimmy'nin eşi, Mr. Wolf, kahve, mahvolan eşyaların derdine düşen Jimmy, gangsterlerin tazyikli suyla yıkanması gibi birbiriyle bağdaşmayan iki referans çerçevesi perspektifinden algılanır, iki farklı dalga boyunda yankılanır ve Koestler'in tabiriyle bisosiasyon gerçekleşir.

İkinci örnekte ise, ırkçılık gibi ciddi bir meselenin bir tarafı, Afrika kökenli Amerikalılar'a karşı olan ırkçı 'beyazlar', beceriksizlikleriyle komik duruma sokulmaktadır. Bugün çoğu seyircinin olumsuz referanslarla algılayacağı, cinayet işlemeye hazırlanan ırkçılar beklenmedik bir biçimde önlerini göremediklerini birbirlerine itiraf etmekte ve bu konuyu uzun uzun tartışmaktadırlar. Normalde seyirci, ırkçı 'beyaz'ların cinayet hazırlığının devamında cinayet bekler ama olayın seyri yukarıda anlatıldığı gibi değişik biçimde gerçekleşerek sürpriz yapar; olağan dışıdır, seyircinin beklentisiyle örtüşmez. Katiller ile beceriksizlik seyirci algısında birbiriyle eşleşmez, bağdaşmaz. Bu bağdaşmazlık gülme tepkisini doğurur.

Yukarıda verilen iki örnek de, gösterildiği üzere, uyuşmazlık kuramıyla açıklanabilecek mizahi sekanslardır. Normal koşullarda gülünmesi düşünülemeyecek cinayet ve şiddet gibi durumlara eşlik ettikleri için kara mizah kategorisinde değerlendirilmelidirler ve Tarantino filmlerinde şiddet ile mizahın iç içeliğini örneklemektedirler.

\section{Sonuc}

Şiddet ile mizah sinemanın başlangıcından bugüne birliktelik içinde olagelmişlerdir ve bu birliktelik yıllar içinde artış göstermiştir. Sinemada şiddet, seyirci için rahatsızlık verici olsa da adaleti sağlamaya yarayan işlevinden dolayı kabul görmekte ve filmlerin neredeyse ayrılmaz bir parçası durumuna gelmektedir. Şiddet, adaleti sağlama işlevinin yanı sıra seyircinin zarar görmeyeceği bir ortamda heyecan ve oyun deneyimi yaşamasına da hizmet etmektedir.

Daha çocukluk yıllarında seyircinin sinemadaki şiddetle ilk tanışmasına aracılık eden şey mizahtır. Mizahın sert bir türü olan ve saçma, anlamsız, mantıksız, çelişik, çizgi dışı, alışıldık olmayan veya komiklik derecesinde alakasız durumlar veya olaylar için kullanılan absürt kavramıyla iç içe geçmiş bulunan kara mizah ise, normalde gülünmesi düşünülemeyecek durum ve kavramları komedileştirmekte, kendisine herhangi bir sınır veya tabu koymamaktadır.

Başlıca karakterleri suç dünyasının içinde ya da kıyısında yaşadıkları için Tarantino filmlerinde şiddet öğelerine bol miktarda rastlanmakla ve hatta şiddet zaman zaman görkemli/abartılı biçimde görselleştirilmekle birlikte, şiddeti kendi içinde amaç olarak ele alan filmlerden farklılıklar da görülmektedir. Bu bağlamda Tarantino filmlerindeki şiddet 'aşırı-gerçek' olan türe girmekte, gerek sekanslarda filmsel zamanın yerini gerçek zamanın almasıyla gerekse de kara mizahın devreye sokulmasıyla, bu tür içinde şiddet hem sıradanlaştırılmakta hem de estetize edilmektedir.

Yönetmenin filmlerindeki beklenmedik, sözlü veya görsel gelişmeler, yaygın kabul gören ve çoğu mizahi durumu açıklayıcı nitelikte olan rahatlama, üstünlük ve uyuşmazlık kuramları içinden uyuşmazlık kuramı yardımıyla analiz edilebilecek nitelikler sergilemektedir. Hollywood filmlerinde pek rastlanmayan uzunlukta ve popüler 
kültüre göndermelerle dolu diyaloglar, bol küfürle ve yaşanmakta olan ciddi, şiddet dolu durumla bir araya geldiğinde, uyuşmazlık kuramının ortaya koyduğu üzere, beklenen ile gerçekleşen durum arasında bir uyuşmazlık oluşmaktadır. Perdede yaşanan tuhaf, olağan dışı ve sürprizli görsel/işitsel olay örgüsü seyircinin duyusal algıları ile soyut bilgisi arasında çatışma yaratmakta ve ortaya kara mizah çıkmaktadır.

Başka bir filmde en dehşet verici olabilecek sahneler Tarantino filmlerinde komik sahnelere dönüşmektedir ve bu, Tarantino filmlerinin en dikkat çekici özelliklerinden biridir. Ancak mizah uğruna eğlenceli bir hale sokularak sıradanlaştırılması, şiddetin normalleştirilmesine katkıda bulunmaktadır. Bunun da sinemacılar, sinema düşünürleri ve öğrencileri tarafından sorgulanması gerektiğini not etmek gerekir. Son tahlilde gülünen şey, bir insan beyninin dağılması durumudur.

\section{Kaynakça}

Appelbaum, Robert (2013). "Notes Toward an Aesthetics of Violence." StudiaNeophilologica. 85 (2): 119-132. doi: 10.1080/00393274.2013.820035.

Batur, Enis (der.) (2010). Kara Mizah Antolojisi. 2. Baskı. İstanbul: Sel Yayıncılık.

Bergson, Henri (2003). Laughter: An Essay on the Meaning of the Comic. Trans. Cloudesley Brereton and Fred Rothwell. The Project Gutenberg Etext.

Breton, André (2009). Anthology of Black Humour. Trans. Mark Polizzotti. London: Telegram.

Camus, Albert (1962). Sisyphe Efsanesi: Uyumsuz Üzerine Deneme. Çev. Tahsin Yücel. İstanbul: Ataç Kitabevi.

Crawley, Tony (1994). "Quentin Tarantino." Film Review. November.

Critchley, Simon (2002). On Humour. London: Routledge.

Freud, Sigmund (1928). "Humour." International Journal of Psychoanalysis. 9: 1-6.

Freud, Sigmund (2012). Espriler ve Bilinçdışı ile İlişkileri. 5. Basım. Freud Kitaplığı: 7. Çev. Dr. Emre Kapkın. İstanbul: Payel.

Giroux, Henry A. (1995). "Pulp Fiction and the Culture of Violence". Harvard Educational Review. 65: 299-314.

Goldstein, Jeffrey (1999). "The Attractions of Violent Entertainment”. Media Psychology. 1 (3): 271-282. doi: 10.1207/s1532785xmep0103_5.

Kant, Immanuel (1987). Critique of Judgment. Trans. Werner S. Pluhar. Indianapolis: Hackett.

Martin, Rod A. (2007). The Psychology of Humor: An Integrative Approach. World Public Library Association. 
McIntosh, William D., John D. Murray, Rebecca M. Murray and Sunita Manian (2009). "What is So Funny About a Poke in the Eye? The Prevalence of Violence in Comedy Films and Its Relation to Social and Economic Threat in the United States, 1951-2000." Mass Communication and Society. 6: 345-360. doi: 10.1207/S15327825MCS0604_1.

Peary, Gerald (der.) (2010). Quentin Tarantino. Çev. Neşfa Dereli. İstanbul: Agora Kitaplığı.

Yokota, Fumie and Thompson, Kimberly M. (2000). "Violence in G-Rated Animated Films." Journal of the American Medical Association. 283 (20): May 24-31.

\section{Filmler}

Affedilmeyen [The Unforgiven]. Yön. Clint Eastwood. 1992. Warner Bros, Malpaso Productions.

Ahmak [The Jerk]. Yön. Carl Reiner. 1979. Aspen Film Society.

Avanak Ajan [The Spy Who Shagged Me]. Yön. Jay Roach. 1999. New Line Cinema, Eric's Boy, Moving Pictures, Team Todd.

Bahçıvan [L'arroseur Arrosé]. Yön. Louis Lumière. 1895. Lumière.

Dehşet Gezegeni [Planet Terror]. Yön. Robert Rodriguez. 2007. Dimension Films, Troublemaker Studios, Rodriguez International Pictures, The Weinstein Company.

Evde Tek Başına 2 [Home Alone 2: Lost in New York]. Yön. Chris Columbus. 1992. Twentieth Century Fox Film Corporation, Hughes Entertainment.

Full Metal Jacket. Yön. Stanley Kubrick. 1987. Natant, Stanley Kubrick Productions, Warner Bros.

Gençlik Yılları [American Grafiti]. Yön. George Lucas. 1973. Universal Pictures, Lucasfilm, The Coppola Company.

Gümüş Eyerler [Blazing Saddles]. Yön. Mel Brooks. 1974. Crossbow Productions, Warner Bros.

İnce Kırmızı Hat [The Thin Red Line]. Yön. Terrence Malick. 1998. Fox 2000 Pictures, GeislerRoberdeau, Phoenix Pictures.

Jackie Brown. Yön. Quentin Tarantino. 1997. Miramax, A Band Apart, Mighty Mighty Afrodite Productions.

Kill Bill Vol.1. Yön. Quentin Tarantino. 2003. Miramax, A Band Apart, Super Cool ManChu.

Kill Bill Vol.2. Yön. Quentin Tarantino. 2004. Miramax, A Band Apart, Super Cool ManChu.

Ölüm Geçirmez [Death Proof]. Yön. Quentin Tarantino. 2007. Dimension Films, Troublemaker Studios, Rodriguez International Pictures, The Weinstein Company.

Pembe Panter'in Dönüşü [The Return of the Pink Panther]. Yön. Blake Edwards. 1975. ITC Films, Incorporated Television Company, Jewel Productions, Pimlico Films, United Artists. 
Rezervuar Köpekleri [Reservoir Dogs]. Yön. Quentin Tarantino. 1992. Live Entertainment, Dog Eat Dog Productions Inc.

Trading Places. 1983. Yön. John Landis. Cinema Group Ventures, Paramount Pictures.

Ucuz Roman [Pulp Fiction]. Yön. Quentin Tarantino. 1994. Miramax, A Band Apart, Jersey Films.

Zincirsiz [Django Unchained]. Yön. Quentin Tarantino. 2012. The Weinstein Company, Columbia Pictures. 